\title{
Diet Composition and Seasonal Fluctuations in the Feeding Habit of Snow Barbel (Schizothorax plagiostomus) in River Indus, Pakistan
}

\author{
Muhammad Qayash Khan 1,2, Muhammad Zubair Anjum', Shamim Akhter', \\ Irfan Khattak ${ }^{3}$, Muhammad Adnan ${ }^{4}$ \& Abid Ali'
}

\begin{abstract}
Background: Schizothorax plagiostomus is widely distributed in river Indus and is most important food fish in Pakistan. The feeding habit of fish is directly related to the size of fish, its metabolic rate and environmental temperature. The accurate description of fish diet and feeding habit is a very important aspect in fisheries management for the purpose of species conservation, breeding and culture. The present work was aimed to investigate the specie abundance, the diet composition and seasonal variations in the feeding habit of Snow barbell Schizothorax plagiostomus.

Materials, Methods \& Results: A total of 1799 fish specimens were caught at the confluence of six tributaries along river Indus at Indus Kohistan, northeastern Pakistan. The fish were collected by 5-panels of gill net during first week of each month. The site specific Catch Per Unit Effort (CPUE) and season specific CPUE of fish fauna were assessed. For the gut content analysis 240 samples (99 male and 141 females) of S. plagiostomus were selected on monthly basis. Frequency of occurrence method and volumetric method were applied to record the different food items in the gut of S. plagiostomus. The physico-chemical parameters, $\mathrm{NO}_{3}$ concentration and dissolved $\mathrm{Co}_{2}$ of water from different localities of river Indus were recorded month wise by Hach sensION 156 meter, Horiba LAQUA Nitrate Meter and EA80 meter respectively. Significant difference was observed in water temperature during the four seasons. Except alkalinity no other water parameter showed significant variation across different localities. The results showed that highest Mean CPUE was observed for Darel Stream (0.55) and lowest for Jalkot stream (0.26). Peak abundance of fish was recorded in the month of November with a mean catch of 44.50, mean CPUE of 0.74 and mean Kruskal-Wallis rank value of 63.25. Spirogyra and Ulothrix occurred as maximum food items in the gut of S. plagiostomus during summer while their minimum amount occurred during autumn. According to the ranking index spirogyra and ulothrix ranked higher with significant difference in comparison to other food items. The results showed that S. plagiostomus is phytophagous in its feeding habit, which consumed mainly algae attached to stones and pebbles during the whole year. However, the presence of some secondary items such as animal matter, detritus, sand and mud might be due to the distinct availabilities of food along the seasons. The highest feeding activity of S. plagiostomus was recorded during summer while the lowest one occurred during autumn, spring and winter. Discussion: Catch per unit effort (CPUE) is an indirect measure of the abundance of a target species. It is used as an index of stock abundance in fisheries and conservation biology. During the study low fish fauna was found in River Indus as reported previously. Majority of the fish occurred in snow fed river tributaries in the study area as these tributaries are comparatively less turbulent. Previous studies have also recorded that Schizothoracine generally prefer clean waters. The present findings of gut contents analysis showed clearly that S. plagiostomus is a phytophagous fish which scrap and consumed spirogyra and ulothrix attached to stones and pebbles. Earlier it was reported that mouth of S. plagiostomusis is inferior, wide, with deep lower jaw having keratinized cutting edge and the lower lip is folded and expanded with numerous papillae making it best suited for scrapping algae attached to stones and pebbles. The highest feeding activity was observed during warmer months as compared to cold months. S. plagiostomus spawn twice in a year in autumn and in spring. The highest feeding activity of $S$. plagiostomus seems to be link with a reflex of recovery strategy due to physiological process of gonadal development.
\end{abstract}

Keywords: Schizothorax plagiostomus, Snow Barbel, feeding habit, seasonal fluctuation, River Indus.

DOI: $10.22456 / 1679-9216.82439$

Received: 18 December 2017

Accepted: 28 March 2018

Published: 29 April 2018

${ }^{1}$ Department of Zoology, Abdul Wali Khan University, Mardan, Khyber Pakhtunkhwa, Pakistan. ${ }^{2}$ Department of Zoology, Pir Mehr Ali Shah Arid Agriculture University, Punjab, Pakistan. ${ }^{3}$ College of Veterinary Science and Animal Husbandry, Abdul Wali Khan University, Mardan. ${ }^{4}$ Department of Zoology, University of Peshawar. CORRESPONDENCE: A. Ali [uop_ali@yahoo.com - Fax: +92 937-843357]. Department of Zoology, Abdul Wali Khan University, Mardan. ZC 23200 Khyber Pakhtunkhwa, Pakistan. 


\section{INTRODUCTION}

Schizothorax plagiostomus is a famous and most important food fish of Pakistan, distributed widely in the mountain and sub-mountain tributaries of river Indus. Catch per unit effort is commonly used method for estimating population size where counting method is difficult to apply. [4,5,8,14,21]. The feeding habit is directly related to the size of fish, its metabolic rate and environmental temperature. Addition of vegetable crops to the food of rainbow trout has significantly enhanced their specific growth and weight gain during the term of experiment [22]. Low water quality may cause overfeeding in fishes due to which chances of pathogen ingestion increases. Deterioration of water quality is a major cause stress in fishes which increases their susceptibility diseases [23]. Diet investigation of a particular fish species is a valuable tool which interpret the trophic relationship in an aquatic ecosystem by providing information about fish life, its position in the food web, food resources and its possible competitors [2]. The accurate description of fish diet and feeding habit is a very important aspect in fisheries management for the purpose of species conservation, breeding and culture. Both extrinsic factors (biotope, region) and intrinsic factors (species, size, behavior) effect the diet of fishes and such information are important to understand the basic functioning of fish assemblage for the purpose of developing Ecosystem Based Fisheries Management Model (EBFM) models $[3,7]$. Assessment of fish feeding habits proved to be very useful in fisheries management and aquaculture. The practices of stomach contents analysis provide a strong insight to assess the fish feeding habit both quantitatively and qualitatively [9].

Keeping in view the importance of Schizothorax plagiostomus in natural fisheries and its role in food web in the ecosystem, the present work has been carried out to get a brief baseline information on its abundance \& distribution, feeding habit and seasonal variations in its food preferences.

\section{MATERIALS AND METHODS}

\section{Experimental design}

The species abundance and feeding habit of snow barbell Schizothorax plagiostomus were studied in river Indus and its tributaries at Indus Kohistan, district of Khyber Pakhtunkhwa Province, northeast- ern Pakistan, located approximately at latitude of $35^{\circ} 15^{\prime} \mathrm{N} 73^{\circ} 30^{\prime} \mathrm{E}$. A total of 1799 S. plagiostomus were collected by 5 -panels of gill net $5 \times 15$ feet (mesh size $1 \mathrm{~cm}, 1.5 \mathrm{~cm}, 2 \mathrm{~cm}, 2.5 \mathrm{~cm}$ and $3 \mathrm{~cm}$ ) during first week of each month in 2016. The traps were settled in a stretch of 3 kilometer from its confluence in each tributary (Jalkot stream, Palas stream, Keyal stream, Barseen stream, Kandia stream and Darel stream). The overall sampling protocol was similar in all sections. Monthwise sampling event lasted for five days and six nights with a maximum soak time of 12-hours.

The physico-chemical parameters such as Water Temperature (WT), pH, Dissolved Oxygen (DO), Conductivity, Hardness, Alkalinity were recorded by Hach sensION 156 meter, $\mathrm{NO}_{3}$ concentration by Horiba LAQUA Nitrate Meter and dissolved $\mathrm{Co}_{2}$ were recorded by EA80 meter. Out of 1799 specimen 240 samples (5.00- $46.00 \mathrm{~cm}$ total length) were selected for gut content analysis to investigate the feeding habit. The selected specimens were preserved in $10 \%$ formalin prior to examination in the laboratory. Individual specimen was weighed to the nearest of $0.1 \mathrm{~g}$ and the total length were taken to the nearest of $0.1 \mathrm{~cm}$. Fish were identified by using the key as prescribed by Nyman \& Swedmar [11].

\section{Gut content analysis}

Each fish specimen was dissected and gut was removed. The gut was weighed (in grams to the nearest of $0.01 \mathrm{~g}$ ) and then preserved in $70 \%$ ethanol solution till analysis. In order to minimize the errors during gut content analysis the anterior most section of the gut was selected as the same was found with the most recent ingested food and was in the better state of gut contents identification. The gut contents were removed into petri dishes, diluted in water and shake well to obtain a homogenous mixture. The homogenous mixture was divided into sub-samples and inspected microscopically for recognition of each food item. Each recognized food item was assigned a value proportional to its abundance. The standard weight (SW) was used as a reference for these values, which is the approximate arithmetic mean of the weight of sample gut content [9]. It was assumed that SW of $5.04 \mathrm{~g}$ (during this study) is equivalent to 4-points and each gut content was assigned a value according to the proportion of their mass in relation to the SW. By visual inspection, the total value obtained were divided among food items according to their relative 
volume. The importance index was calculated according to the method described by Lima-Junior \& Goitein [9]. The mean ascribed values of each food item were obtained by summing up of points given to each food item divided by total number of guts in the sample. The arithmetic mean thus obtained were then multiplied by a multiplication constant. From such calculation, volumetric analysis index (Vi) values were obtained ( $\mathrm{Vi}=25 \mathrm{Mi}$ ). The Importance Index of each food item was calculated through multiplication of Volumetric analysis Index (Vi) values with the values of Frequency of occurrence (Fi) as described by Lima-Junior and Goitein [9] (AIi = Fi .Vi). The results obtained were statistically analyzed by the method where the food items were ranked in each sample. [9] The values of Importance Index obtained in different seasons were compared through Kruskal-Wallis Test [20]. The ranking was compared by Spearman rank correlation coefficients, in which the correlation was considered statistically significant at $P<0.05$.

\section{RESULTS}

A total of 240 fish having an average size of 5 to $46 \mathrm{~cm}$ (total length) were selected for feeding assessment caught from the river Indus and its tributaries during the year 2015-16. The gut contents of 99 male and 141 females were analyzed to investigate the diet composition and seasonal fluctuations in the feeding habit of Snow Barbel (Schizothorax plagiostomus).

\section{Physico-chemical parameters of the water}

Physico-chemical parameters of water from different localities (Jalkot stream, Palas stream, Keyal stream, Barseen stream, Kandia stream and Darel stream) on river Indus were recorded month-wise. The sampling data was pooled by seasons i.e. autumn (September, October \& November), winter (December, January \& February), spring (March, April \& May) and summer (May, June, July \& August) on the basis of water temperature. The average water temperature was recorded as $10.93^{\circ} \mathrm{C}, 9.79^{\circ} \mathrm{C}, 15.28^{\circ} \mathrm{C}$ and $20.91^{\circ} \mathrm{C}$ in autumn, winter, spring and summer respectively. The difference in mean water temperature during the four seasons was statistically significant $(P<0.05)$ as shown in Table 1 . The mean water temperature of all categories of localities was similar $(P>0.05)$. Similarly DO, conductivity, hardness and alkalinity from different localities of the river Indus showed significant differences during the four seasons. However, insignifi- cant variations were recorded for the above parameters across different localities except alkalinity that showed significant variations $(P<0.05)$. Seasonal variations in the concentration of $\mathrm{NO}_{3}$, water $\mathrm{pH}$ and dissolved $\mathrm{CO}_{2}$ throughout the year were found non-significant across categories of seasons and sampling sites as well.

\section{Fish distribution and abundance}

Variations in S. plagiostomus abundance were found significant at the confluence of different tributaries along river Indus (Table 3). The maximum sampling were done at Darel stream with a mean catch of 33.17, mean CPUE of 0.55 and a mean Kruskal-Wallis rank value of 47.74 while a minimum sampling were made at Jalkot stream with a mean catch of 15.83 , mean CPUE of 0.26, mean Kruskal-Wallis rank value of 22.96 and a $P$-value of 0.040 . Similarly the variations in the number of this species was found significant across different seasons. The lowest number of S. plagiostomus recorded in August with a mean catch of 7.17, mean CPUE of 0.12 and a mean Kruskal-Wallis rank value of 8.42. A peak abundance of fish was recorded in the month of November with a mean catch of 44.50 , mean CPUE of 0.74, mean Kruskal-Wallis rank value of 63.25 and a $P$-value of 0.000 .

\section{Fish Diet}

The mean importance index of different food items consumed by S. plagiostomus in four season are shown in Figure 2. Spirogyra and Ulothrix occurred as maximum food items in the gut of S. plagiostomus during summer while their minimum amount occurred during autumn. Both these items constitute the major food of S. plagiostomus found almost throughout the four seasons. Considerable amount of Mayflies, Caddis flies and Sand and mud were collected during winter and autumn. In addition, a considerable amount of sand and mud were found in the gut during summer and spring. The gut of S. plagiostomus contained traces of detritus throughout the year. These finding revealed that aquatic algae Spirogyra and Ulothrix constitute the main food of S. plagiostomus, collected from river Indus and its tributaries independently of seasonal effects. However, other organisms such as Mayflies, Caddis flies and detritus were also found in the stomachs of sampled individuals.

According to the ranking index Spirogyra and Ulothrix ranked higher with significant difference in comparison to other food items $(P<0.05$, Kruskal- 
Wallis test). The concentration of Spirogyra and Ulothrix was significantly higher among other diet contents (Table 5) which revealed that S. plagiostomus is a phytophagous fish, however the presence of other food items shows omnivorous and opportunist feeding habit.
Regarding the seasonal dietary shift, it was observed that the food items consumed by the species, shows higher importance index during summer followed by spring. The lowest importance index was recorded during autumn followed by winter (Table 4).

Table 1. Mean values of Physico-chemical parameters of water in all seasons from Indus River and its tributaries at Khyber Pakhtunkhwa Province, northeastern Pakistan.

\begin{tabular}{|c|c|c|c|c|c|}
\hline \multirow{2}{*}{ Physico-chemical properties } & \multicolumn{4}{|c|}{ Seasons } & \multirow[t]{2}{*}{$P$-Value } \\
\hline & Autumn & Winter & Spring & Summer & \\
\hline Water Temp. $\left({ }^{\circ} \mathrm{C}\right)$ & 10.93 & 9.79 & 15.28 & 20.91 & 0.000 \\
\hline $\mathrm{pH}$ & 7.32 & 7.60 & 7.67 & 7.80 & 0.135 \\
\hline $\mathrm{DO}(\mathrm{mg} / \mathrm{L})$ & 8.36 & 9.08 & 9.75 & 10.11 & 0.030 \\
\hline Conductivity (uS/cm) & 47.54 & 69.58 & 82.33 & 107.50 & 0.000 \\
\hline Hardness (mg/L) & 86.75 & 81.33 & 87.17 & 98.41 & 0.035 \\
\hline Alkalinity (mg/L) & 63.36 & 64.00 & 63.83 & 78.25 & 0.05 \\
\hline Nitrate (mg/L) & 0.83 & 0.95 & 0.69 & 0.88 & 0.232 \\
\hline Dissolved $\mathrm{CO}_{2}(\mathrm{mg} / \mathrm{L})$ & 14.71 & 15.83 & 15.50 & 15.67 & 0.625 \\
\hline
\end{tabular}

The mean difference is significant at $P<0.05$ level.

Table 2. Mean values of Physico-chemical parameters of water from various localities of Indus River and its tributaries at Khyber Pakhtunkhwa Province, northeastern Pakistan.

\begin{tabular}{cccccccc}
\hline \multirow{2}{*}{ Physico-chemical properties } & \multicolumn{3}{c}{ Localities/Sampling sites } & \multicolumn{3}{c}{$P$-Value } \\
\cline { 2 - 8 } & $\begin{array}{c}\text { Jalkot } \\
\text { stream }\end{array}$ & $\begin{array}{c}\text { Palas } \\
\text { stream }\end{array}$ & $\begin{array}{c}\text { Keyal } \\
\text { stream }\end{array}$ & $\begin{array}{c}\text { Barseen } \\
\text { stream }\end{array}$ & $\begin{array}{c}\text { Kandia } \\
\text { stream }\end{array}$ & $\begin{array}{c}\text { Darel } \\
\text { stream }\end{array}$ \\
\hline Water Temp. $\left({ }^{\circ} \mathrm{C}\right)$ & 14.56 & 14.33 & 14.43 & 13.73 & 13.28 & 15.02 & 0.990 \\
pH & 7.43 & 7.56 & 7.62 & 7.27 & 7.85 & 7.85 & 0.168 \\
DO $(\mathrm{mg} / \mathrm{L})$ & 8.75 & 9.21 & 9.76 & 10.03 & 9.12 & 9.07 & 0.624 \\
Conductivity $(\mathrm{mg} / \mathrm{L})$ & 76.06 & 91.75 & 72.25 & 75.37 & 71.75 & 73.25 & 0.645 \\
Hardness $(\mathrm{mg} / \mathrm{L})$ & 83.63 & 92.63 & 85.00 & 81.75 & 87.63 & 99.88 & 0.14 \\
Alkalinity $(\mathrm{mg} / \mathrm{L})$ & 59.78 & 67.50 & 68.87 & 59.38 & 74.62 & 74.12 & 0.039 \\
Nitrate $(\mathrm{mg} / \mathrm{L})$ & 0.80 & 0.82 & 0.98 & 0.80 & 0.91 & 0.80 & 0.966 \\
Dissolved $\mathrm{CO}_{2}(\mathrm{mg} / \mathrm{L})$ & 14.33 & 14.75 & 16.36 & 17.00 & 15.50 & 14.62 & 0.114 \\
\hline
\end{tabular}

The mean difference is significant at $P<0.05$ level.

Table 3. Schizothorax plagiostomus abundance in different tributaries along river Indus at Khyber Pakhtunkhwa Province, northeastern Pakistan.

\begin{tabular}{|c|c|c|c|c|}
\hline Collection Sites & Mean Catch & \multicolumn{2}{|c|}{ Mean CPUE } & Mean Kruskal-Wallis rank Values \\
\hline Jalkot Stream & 15.83 & 0.26 & & 22.96 \\
\hline Palas Stream & 19.50 & 0.32 & & 28.33 \\
\hline Keyal Stream & 25.00 & 0.41 & $P$ Value & 37.21 \\
\hline Barseen Stream & 28.33 & 0.47 & 0.04 & 41.13 \\
\hline Kandia Stream & 28.08 & 0.46 & & 41.63 \\
\hline Darel Stream & 33.17 & 0.55 & & 47.75 \\
\hline
\end{tabular}

The mean difference is significant at $P<0.05$ level. 
Table 4. Seasonal variations in abundance of Schizothorax plagiostomus in tributaries of river Indus at Khyber Pakhtunkhwa Province, northeastern Pakistan.

\begin{tabular}{|c|c|c|c|}
\hline Collection Months & Mean Catch & Mean CPUE & Mean Kruskal-Wallis rank Values \\
\hline January & 20.17 & \multirow{8}{*}{$\begin{array}{c}P \text { Value } \\
0.000\end{array}$} & 31.67 \\
\hline February & 20.67 & & 31.67 \\
\hline March & 29.00 & & 41.92 \\
\hline April & 41.67 & & 59.83 \\
\hline May & 24.33 & & 36.92 \\
\hline June & 14.17 & & 21.25 \\
\hline July & 7.67 & & 8.83 \\
\hline August & 7.17 & & 8.42 \\
\hline September & 29.00 & 0.48 & 43.50 \\
\hline October & 42.17 & 0.70 & 59.83 \\
\hline November & 44.50 & 0.74 & 63.25 \\
\hline December & 19.33 & 0.32 & 30.92 \\
\hline
\end{tabular}

The mean difference is significant at $P<0.05$ level.

Table 5. Mean importance Index of food items consumed by Schizothorax plagiostomus.

\begin{tabular}{cccc}
\hline Food items & $\begin{array}{c}\text { Mean importance Index } \\
\text { of food items }\end{array}$ & $\begin{array}{c}\text { Mean ranks of } \\
\text { importance Index }\end{array}$ & Seasons \\
\hline Spirogyra & 7520.35 & 21.00 & Autumn, winter, spring and summer \\
Ulothrix & 5703.97 & 20.00 & Autumn, winter, spring and summer \\
Mayflies & 502.29 & 7.00 & Autumn and winter \\
Caddis flies & 512.63 & 7.25 & Autumn and winter \\
Sand \& mud & 591.16 & 8.25 & Autumn, winter, spring and summer \\
Detritus & 878.97 & 11.50 & Autumn, winter, spring and summer \\
\hline The mean difference is significant at $P<0.05$ level. & &
\end{tabular}

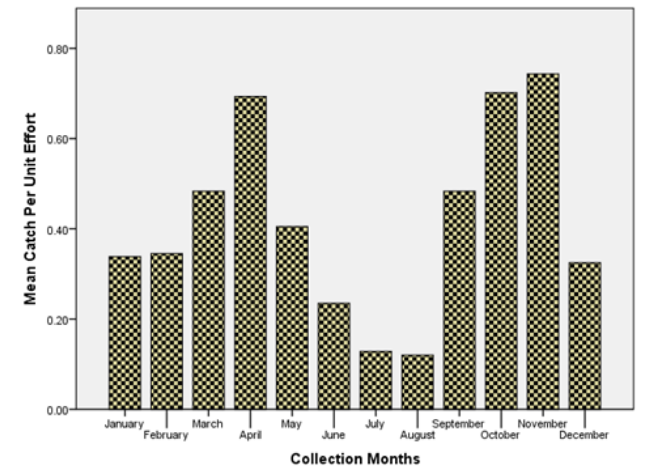

Figure 1. Bar graph showing monthly variations in mean CPUE of Schizothorax Plagiostomus caught during January to December 2016 at the confluence of six tributaries along river Indus at Khyber Pakhtunkhwa Province, northeastern Pakistan.

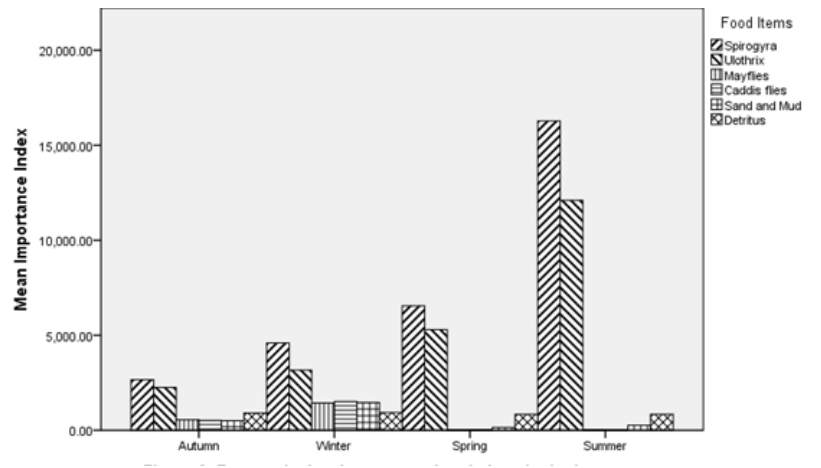

Figure 2. Bar graph showing seasonal variations in the importance index of different food items collected from the gut of Schizothorax Plagiostomus during December 2016 at the confluence of six tributaries along river Indus at Pakhtunkhwa Province, northeastern Pakistan. 


\section{DISCUSSION}

The knowledge about fish food and feeding habit has a basic importance in the area of fisheries management and conservation. The present work was designed to investigate species abundance, distribution and the food composition of S. plagiostomus and its seasonal variations. In northern areas of Pakistan River Indus is highly torrential which passes through narrow gorges having high sediment load leading to poor Ichthyo-diversity. During this survey the low fish fauna was found in River Indus which tally the findings of Rafique [13], that the fish fauna of river Indus is constituted by 177 fish species including 12 exotic species which is substantially lower than other major rivers in Asia like Ganges (350 species), Brahamputra, Mekong (400) \& Hwang Hu (320 species).

Majority of the species caught during this study belonged to Schizothorax genus. During summer the water of the main stem river are highly turbulent with maximum sediment load. The water of snow fed river tributaries in the study area are also turbulent however, to a lesser extent in comparison to the main stem river. The low sediment load and clarity of water attract the upstream migration of fish to these tributaries both for searching food and spawning. This is in agreement to the findings of Yousuf et al. [19], who revealed that species of Schizothoraxine generally prefer clean waters.

The mean Kruskal-Wallis rank values regarding species abundance and CPUE of S. plagiostomus calculated in this study was fairly high in Darel stream followed by Kandia and Barseen streams. The high level of nitrate, hardness and DO recorded in these shallow streams during summer and spring seems to facilitate the food availability through growth of Spirogyra and Ulothrix due to which the fish species are more abundant. These results are supported by the finding of Palma and Andrade [12] that factors such as food availability, salinity and temperature may affect fish morphometry and its population.

The present finding revealed that $S$. plagiostomus was the most dominant fish species in fast flowing torrential waters collected from different streams joining river Indus (Jalkot stream, Palas stream, Keyal stream, Barseen stream, Kandia stream and Darel stream) in the study area. In line with this Yousuf [18] investigated that the dominance of $S$. plagiostomus throughout Liddar river in Kashmir seems to be related to its love for fast flowing water in torrential which is present both in low and high depth and velocity.

Several authors worked on the feeding habit of S. plagiostomus $[1,15]$. The gut contents of S. plagiostomus were analyzed by the calculation of frequency of occurrence, volumetric analysis and Importance Index where the points were attributed to each food item found in fish stomach. The same method was described by Lima-Junior and Goitein [9]. According to feeding habits, adult fish are classified as herbivores (phytophagous), if their food comprise of vegetable matter, carnivore, if they feed on animal matter, and omnivore if they consume mixed diet comprised of both animal food as well as vegetable.

The present findings of gut contents analysis clearly showed that $S$. plagiostomus is a phytophagous fish which scrap and consumed spirogyra and ulothrix attached to stones and pebbles. Similar finding were reported by Sharma [15]. The mouth of S. plagiostomusis is inferior, wide, with deep lower jaw having keratinized cutting edge. The lower lip is folded and expanded with numerous papillae making it best suited for scrapping algae attached to stones and pebbles. Similar adaptations in the mouth of $S$. plagiostomus were described by [11].

The analysis of gut contents during this study revealed that $S$. plagiostomus feeds on aquatic algae such as Spirogyra and Ulothrix which constitutes its major food while considerable amount of other food items such as Mayflies, Caddis flies, detritus and sand and mud were also found. This is in line with the findings of Singh et al. [16] and Bahuguna et al. [1].

The highest feeding activity of $S$. plagiostomus were observed during summer and spring. The results showed that $S$. plagiostomus eats more during warmer months than what is observed in the cold months. $S$. plagiostomus spawn twice in a year in autumn and in spring. The highest feeding activity of S. plagiostomus seems to be link with a reflex of recovery strategy due to physiological process of gonadal development. Similar results were found by Lima Junior and Goitein [10] working on the feeding activity of Pimelodus maculatus.

Statistically no significant difference was observed in the ranking of different food items across all seasons when the seasonal data was compared. However, the clear drop in the importance index of the main food items (Spirogyra and Ulothrix) added to 
smaller stomach fullness indexes observed in autumn and winter, showed a decrease in feeding activity at a transition between the seasons. In agreement to this the findings of others researchers $[6,10,17]$ states that the fish feeding rate is directly proportional to environmental temperature.

\section{CONCLUSION}

The adjoining tributaries of river Indus in the study area has a good population of S. plagiostomus, an indigenous fish of economic importance. These tributaries has a great advantage by providing shelter from high sediment load observed during summer in the main stem Indus river, provision of the benthic food and spawning opportunity. The study area has a minimum anthropogenic activity to date but the proposed and approved power generation projects such as Dasu Hydel Project and Diamer Basha Dam will impose a serious threat to the biodiversity in the area. It is suggested that fish ways should be included in the mentioned projects on priority basis in order to facilitate fish migration and its conservation in the main stem river.

Declaration of interest. The authors report no conflicts of interest. The authors alone are responsible for the content and writing of the paper.

\section{REFERENCES}

1 Bahuguna S., Negi R., Bahuguna P. \& Upadhyay M. 2008. Ex-situ developmental study of Schizothorax plagiostomus from pre to post hatching. Journal of Environment and Bio-Sciences. 22: 67-76.

2 Cardone I.B., Lima-Junior S.E. \& Goitein R. 2006. Diet and capture of Hypostomus strigaticeps (Siluriformes, Loricariidae) in a small brazilian stream: relationship with limnological aspects. Brazilian Journal of Biology. 66: 25-33.

3 Hanson J. \& Chouinard G. 2002. Diet of Atlantic cod in the southern Gulf of St Lawrence as an index of ecosystem change, 1959-2000. Journal of Fish Biology. 60: 902-22.

4 Harley S.J., Myers R.A. \& Dunn A. 2001. Is catch-per-unit-effort proportional to abundance? Canadian Journal of Fisheries and Aquatic Sciences. 58: 1760-1772.

5 Hinton M.G. \& Maunder M.N. 2003. Methods for standardizing CPUE and how to select among them. Collective Volume of Scientific Papers. ICCAT. 56: 169-177.

6 Stevens M., Maes J. \& Ollevier F. 2006. A bioenergetics model for juvenile flounder Platichthys flesus. Journal of Applied Ichthyology Ruary. 22: 79-84.

7 Kullander S.O., Fang F., Delling B. \& Ahlander E. 1999. The fishes of the Kashmir Valley. In: Nyman L. (Ed). River Jhelum, Kashmir Valley: Impact on the Aquatic Environment. Goteberg: Swedmar, pp.100-167.

8 Kulbicki M., Guillemot N. \& Amand M. 2005. A general approach to length-weight relationships for New Caledonian lagoon fishes. Cybium. 29: 235-52.

9 Laloë F., Pecha N., Sabatierb R. \& Sambac A. 1998. Model identification for flexible multifleet-multispecies fisheries: a simulation study. Fisheries Resarch. 37: 193-202.

10 Lima Junior S.E. \& Goitein R. 2001. A new method for the analysis of fish stomach contents. Acta Scientiarum. 23: 421-424.

11 Lima Junior S.E. \& Goitein R. 2004. Diet and feeding activity of Pimelodus maculatus (Osteichthyes, Pimelodidae) in the Piracicaba River (State of São Paulo, Brazil)-The effect of seasonality. Boletim do Instituto de Pesca. 30: 135-140.

12 Nisha R.G., Rajathi V., Manikandan R. \& Prabhu N.M. 2014. Isolation of Plesiomonas shigelloides from infected cichlid fishes using $16 \mathrm{~S}$ rRNA characterization and its control with probiotic Pseudomonas sp. Acta Scientiae Veterinariae. 42: 1-7.

13 Palma J. \& Andrade J. 2002. Morphological study of Diplodus sargus, Diplodus puntazzo, and Lithognathus mormyrus (Sparidae) in the Eastern Atlantic and Mediterranean Sea. Fisheries Research. 57: 1-8.

14 Rafique M. 2000. Fish diversity and distribution in Indus River and its drainage system. Pakistan Journal of Zoology. 32: $321-32$.

15 Schaefer M.B. 1954. Some aspects of the dynamics of populations important to the management of the commercial marine fisheries. Inter-American Tropical Tuna Commission Bulletin. 1: 23-56.

16 Sharma R. 1994. Qualitative and quantitative seasonal variation in feeding of snow trout, Schizothorax plagiostomus (Heckel) of Garhwal Himalaya. Biological bulletin of India. 6: 20-25. 
17 Sheikhzadeh N. 2013. Influence of dietary vegetable crops on rainbow trout (Oncorhynchus mykiss) immune system and growth performance. Acta Scientiae Veterinariae. 41: 1-6.

18 Singh N., Bahuguna S. \& Bhatt K. 1993. The profile of river ecosystem, food and feeding habits of hills-tream fishes and consequences of recent enviromental degradation in Garhwal Himalaya. Acta Ichthyologica et Piscatoria. 23: 3-30.

19 Wootton R.J. 1990. Ecology of Teleost fishes. New York: Chapman \& Hall, 404p.

20 Yousuf A.R. 1996. Fishery resource of Kashmir. In: Khan A.H. \& Pandit A.K. (Eds). Ecology, Environment and Energy. Srinagar: University of Kashmir, pp.75-120.

21 Yousuf A., Bhat F., Mehdi D., Ali S. \& Ahangar M. 2003. Food and feeding habits of Glyptosternon reticulatum McClelland and Griffth in torrential streams of Kashmir Himalayas. Journal of Research and Development. 3: 124-133.

22 Zar J. 1999. Circular distributions: descriptive statistics and circular distributions: hypothesis testing. In: Biostatistical analysis. 4th edn. Upper Saddle River: Prentice Hall, pp.592-663.

23 Zimmerman J.K. \& Palo R. 2011. Reliability of catch per unit effort (CPUE) for evaluation of reintroduction programs - A comparison of the mark-recapture method with standardized trapping. Knowledge and Management of Aquatic Ecosystems. (401). 07: 1-8. 